\title{
犬近位尿道に関する薬理学的研究
}

\author{
一特に排尿時弛緩機構について一 \\ 福島県立医科大学泌尿器科学教室 \\ (主任: 白岩康夫教授) 小林正人
}

\section{PHARMACOLOGICAL ANALYSIS ON FUNCTION OF THE CANINE PROXIMAL URETHRA}

\author{
Masato Kobayashi \\ Department of Urology, Fukushima Medical College \\ (Director: Prof. Y. Shiraiwa)
}

The function of the proximal urethra was studied using muscle strips taken from female mongrel dogs. These strips were dissected in as circular or as longitudinal fashions.

In both circular and longitudinal muscle strips, phenylephrine and norepinephrine caused a dosedependent contraction, while isoproterenol caused a dose-dependent relaxation. Since the contraction and relaxation responses were blocked by prazosin and propranolol, these responses were mediated by alpha and beta adrenergic receptor mechanisms.

In the longitudinal muscle strips, stimulation with acetylcholine (Ach) caused a dose-dependemt contraction. Similar to the response of the detrusor muscle, this response which was blocked by atropine, is suggesting that the lingitudinal muscle of the proximal urethra is an element of the detrusor muscle. However, circular urethral muscle strips showed and initial small contraction and subsequent relaxation on stimulation with Ach. These responses were not blocked by atropine, but were able to be bolcked by alpha and beta adrenoceptor blocking agents (prazosin and propranolol). Under administration of tetrodotoxin or hexamethonium, Ach produced niether contraction nor relaxation. These results suggested that Ach stimulates intramural ganglion cells belonging to the sympathetic system which results in a release of norepinephrine at nerve endings while activation of alpha and beta adrenoceptors in the proximal urethral musculature. Furthermore, Ach caused rapid relaxation when it was given during the course of a contraction induced by norepinephrine.

From these results it would be conculuded that at micturition, relaxation of circular muscle should occur through short adrenergic neurons, when shortning of the longitudinal muscle is caused by the contraction of the detrusor muscle element.

要旨：雑種雌成犬を用い, in vitro studyにより近位尿道機能を薬理学的に検討した.

近位尿道は, 周方向および軸方向筋切片ともに交感神経刺激剤に対して $\alpha_{1}$ 受容体を介する収縮反応 と, $\beta$ 受容体を介する弛緩反応を示した. acetylcholine 刺激に対しては, 軸方向筋切片ではムスカリン 性受容体を介する収縮反応を示したが, 周方向筋切片では acetylcholine $100 \mu \mathrm{g} / \mathrm{ml}$ 投与時に, 初めの小 さな収縮反応に引き続き大きな弛緩反応が出現した。この反応は atropineにては抑制されず，hexamethonium, tetrodotoxin 前投与により消失した. DMPPは acetylcholine と同じ反応を引き起こし た。 また，初めの収縮反応は prozosinにより，後の弛緩反応は propranololにより消失した。したがっ

て, 近位尿道周方向筋切片は, acetylcholine のニコチン様作用により short adrenergic neuron の所属 する壁内神経節が刺激された結果 norepinephrine が放出され， $\alpha_{1}$-および $\beta$ 受容体を介する 2 相性の反 応を引き起こしたものと考兄られた，更に，norepinephrine 投与により収縮反応を引き起こした周方向 筋切片に acetylcholine を投与すると， $\beta$ 受容体を介する急速な弛緩反応のみが出現した。 
以上より排尿時における近位尿道の弛緩機構は, 排尿筋成分による縦方向の収縮が起り尿道が短縮す ると同時に, short adrenergic neuron の関与によって周方向の弛緩が起こり, 両者の相互作用によって 増強されるものと思われた。

\section{はじめに}

膀胱䅡部も含めて近位尿道全体は内括約筋あるいは 平滑筋性括約筋 (smooth muscle sphincter) と呼ばれ, 蓄尿期に抢ける尿保持機能の他，排尿期に括ける弛緩 機構も有し，抢互いに相反する機能を営む場所として 知られている。解剖学的にも近位尿道の筋構築は複雑 で1) 3)括約作用に関与する自律神経の支配形式や神経 受容体 (receptor)の分布についてもまだ一定の見解が 確立されていない。さらに，排尿時の弛緩機構につい ても多くの説が提唱されている，その一つは，排尿筋 の一部が近位尿道まで入りこむ所見を根拠とした Lapides $^{4)}$, Woodburne ${ }^{5)}$ 拉よび Hutch ${ }^{6}$ に代表される 䅡部の機械的開口説 (mechanical opening theory) で ある.一方では, Elbadawi ${ }^{7)}$ や Schluman ${ }^{8)}$ の報告以来, 近位尿道に颃いて末梢神経節レベルにある交感神経の 相互連絡機構が重視されるようになり ${ }^{97}$, 臨床的にも smooth muscle sphincter $の$ dyssynegia が認められ るに及び10)，排尿筋と smooth muscle sphincter の協 調運動には神経性調節機構が関与する可能性も出てき た ${ }^{11)}$.

このように複雑な近位尿道機能を理解するために は，単に尿道全体の反応を問題にするだけでなく，近 位尿道に打ける各部位と筋構築との関係も考虑した系 統的実験が必要と思われる。そこで本研究では, 近位 尿道から軸方向や上から順次周方向に連続的に切除し た筋切片を対象に, 自律神経薬に対する特徵的反応に ついて再検討を加えた。ささらに acetylcholine（以下 Ach と略す）による反応を基にして，近位尿道へ入り 込んでいる排尿筋成分之尿道固有の平滑筇成分との薬 理学的反応を分析したところ, 興味ある知見を得たの で報告する。

\section{実験材料および方法}

43頭の雑種雌成犬（体重7 11 kg）を thiamylal 麻酔 下に開腹し,膀脱および近位尿道を一塊として摘出し, $4^{\circ} \mathrm{C}$ Krebs-Ringer 液 $\left(\mathrm{NaCl} 118.0, \mathrm{KCl} 4.7, \mathrm{CaCl}_{2}\right.$ 1.3, $\mathrm{MgSO}_{4} 1.2, \mathrm{NaHCO}_{3}$ 25.0, $\mathrm{KH}_{2} \mathrm{PO}_{4}$ 117.0, glucose $11.1 \mathrm{mM}, \mathrm{pH} 7.4)$ 中に保存した後, 筋組織 標本片（以下，筋切片とす）を作成した。

はじめに，膀胱体部から筋切片を採取した。次いで 尿管口の高さより約 $5 \mathrm{~mm}$ 下方を膀胱䅡部とし, これよ
り近位尿道にかけて周方向に筋切片を切除した。周方 向筋切片の大きさは, 平均 $10 \times 2 \mathrm{~mm}$ とし, 一頭につき $3 \sim 4$ 切片を採取した。 また近位尿道の前壁と後壁か ら軸方向に筋切片を切除し, $15 \times 2 \mathrm{~mm}$ の軸方向筋切片 を 1 頭につき 2 切片採取した (Fig. 1). 筋切片は粘膜 を小直剪刀にて除去した後，6-0絹系にて両端を結び， その一方を organbath内のフックに, 他端を isometric transducer (日本光電社製 FD ピックアッ プ)に固定し垂直懸垂した。 organbath は容積 $50 \mathrm{ml}$ で, 栄養液には Krebs-Ringer 液を用い $37^{\circ} \mathrm{C} に$ 保持し,

Fig. 1 管切片採取部位.

1. 膀胼体部筋切片. 2. 近位尿道周方向筋切片. 3 . 近位尿道前壁軸方向筋切片. 4. 近位尿道後壁軸方向 筋切片.

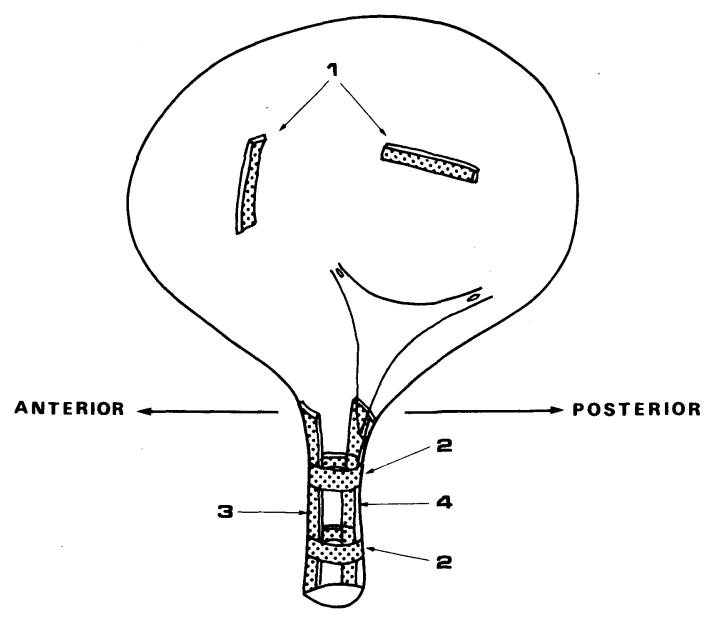

Fig. 2 筋切片を用いた in vitro study の模式困

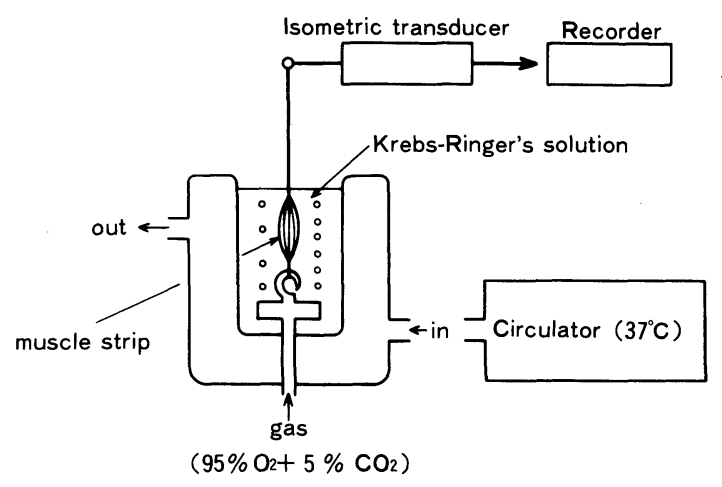


$95 \% \mathrm{O}_{2}+5 \% \mathrm{CO}_{2}$ の混合ガスを通気した．筇切片には $1.0 \mathrm{~g}$ の張力を負荷後, 60 分以上放置してから張力の変 化を等尺性にポリグラフに記録した。記録紙のスピー

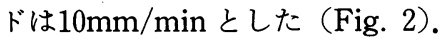

使用した薬剤は, acetylcholine chloride (Ovisot： 第一) atropine sulfate (Atropine：田辺), norepinephrine hydrochloride (Noradrenaline : 三共), isoproterenol (Protanol：日研), prazosin hydrochloride (Minipress: 台糖ファイザー), propranolol hydrochloride (Inderal: ICI), hexamethonium bromide (Methobromin:山之内), tetrodotoxin (Tetrodotoxin: Sigma), 1-1 dimethyl-4-phenylpiperadinium (DMPP : Sigma), papaverine hydrochloride（塩酸パパベリン：大日本）である.

\section{結果}

1. Ach に対する各部位の反応

はじめに，対照として排尿筋である膀胼体部筋の 10 切片について検討を行った。排尿筋は周方向でも軸方 向でも, Ach に対して同様の反応を示した. Fig. 3に示 すように, 排尿筋切片は Ach を $1 \mu \mathrm{g} / \mathrm{ml}$ から $100 \mu \mathrm{g} / \mathrm{ml}$
まで濃度を変化させて投与すると濃度依存性の収縮反 応を起こした。これらの反応は atropine を $0.05 \mu \mathrm{g} / \mathrm{ml}$ 前投与すると完全に抑制され，ムスカリン性受容体を 介するものと思われた。 な和種々の濃度の Ach に対す る反応を検討したところ，排尿筇切片の反応は $100 \mu \mathrm{g} /$ $\mathrm{ml}$ の濃度を起えると飽和状態を示した。この濃度は諸 家の報告による常用量とほぼ一致し生理的な飽和濃度 と考兄られるので，以下の実験には $100 \mu \mathrm{g} / \mathrm{ml}$ をお に使用し，必要に応じてこれ以下の濃度についても検 討した。

a）周方向筋切片

膀胱䅡部より採取した10切片について検討したとこ ろ, Ach $100 \mu \mathrm{g} / \mathrm{ml}$ 投与時には急な立ち上りをもつ収 縮波が出現し，これに続いて排尿筋の場合と同じ tonic な収縮反応が持続した。しかし atropine 0.05 $\mu \mathrm{g} / \mathrm{ml}$ を前投与すると, tonic な収縮反応は全体とし て抑制されたが，前半のスパイク状収縮波は抑制され ずこれれりき続き他緩反応が出現した (Fig. 4). し たがって，膀胱頝部に招いてはムスカリン性受容体を 介する収縮反応と同時に, atropine で抑制されないも

Fig. 3 膀胼体部筋切片に抢ける acetylcholine の反応（左）． atropine 投与後の acetylcholine の反応（右）。反応は完全に抑制される。市：洗浄

\section{Detrusor muscle}

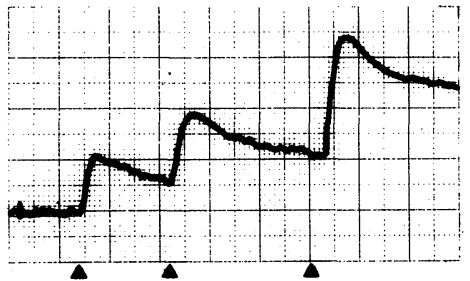

Ach $1 \mu \mathrm{g} / \mathrm{ml} 10 \mu \mathrm{g} / \mathrm{ml} \quad 100 \mu \mathrm{g} / \mathrm{ml}$
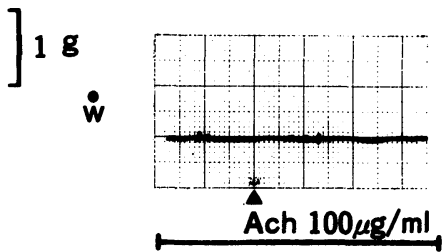

Atropine $0.05 \mu \mathrm{g} / \mathrm{ml}$

Fig. 4 膀胱䅡部周方向筋切片に招ける acetylcholine の反応 (左). atropine 前投与 後の acetylcholine の反応 (右)。スパイク状の収縮波は抑制されず引き続き弛緩反 応が出現した。 $\dot{\mathrm{w}}$ : 洗浄

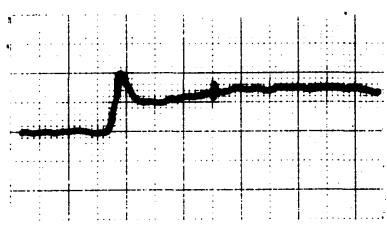

$\Delta$

Ach $100 \mu \mathrm{g} / \mathrm{m} \ell$

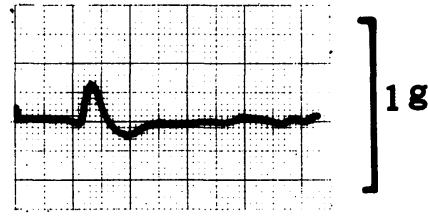

$\Delta$

Ach $100 \mu \mathrm{g} / \mathrm{ml}$

atropine $0.05 \mu \mathrm{g} / \mathrm{m} \ell$ 
らひとつ別の反応が生ずることが示唆された.

次に近位尿道周方向筋切片120個につき, Ach に対

する反応を検討した。 その結果, Ach $100 \mu \mathrm{g} / \mathrm{ml}$ 投与
時には，はじめに収縮し後に弛緩する 2 相性の反応が 97切片に観察され, 15切片では収縮反応のみが出現し, 8 切片には弛緩反応のみが観察された (Fig. 5).これ

Fig. 5 近位尿道周方向筋切片に括ける acetylcholine の反応.

A. 2 相性反応. $n=97$. B. 収縮反応. $n=15$. C. 弛緩反応, $n=8, n$ は筇切片の 数を表わす。
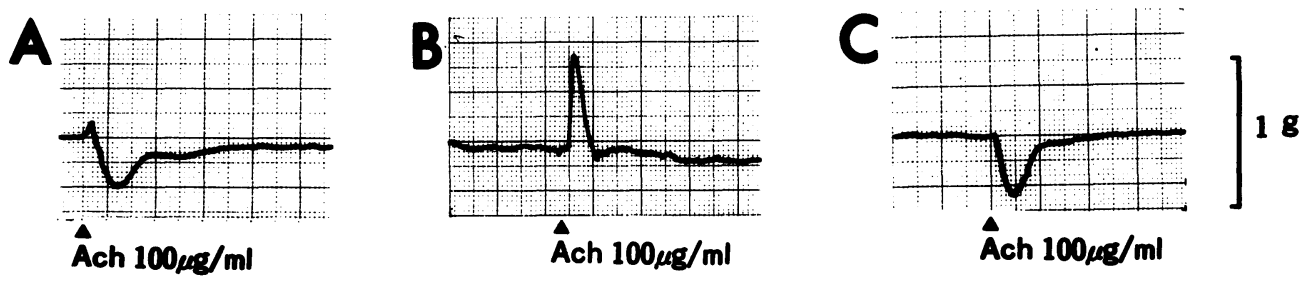

Fig. 6 近位尿道周方向筋切片の Ach の効果に対する atropine の影響. acetylcholine の反応 (左). atropine 前投与後の acetylcholine の反応 (右). 反応 はほとんど影響を受けない。市：洗浄。

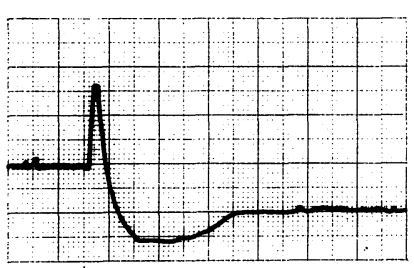

Âch $100 \mu \mathrm{g} / \mathrm{ml}$

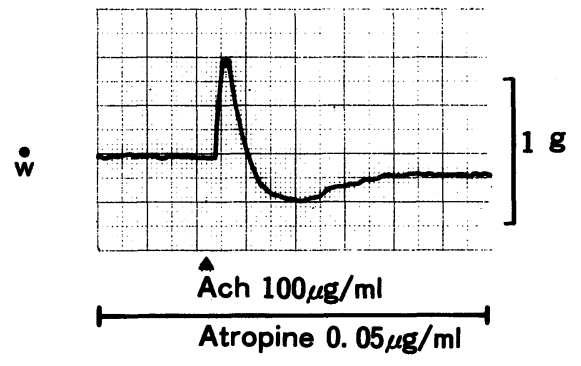

Fig. 7 近位尿道軸方向筋切片に拈ける acetylcholine の反応.

A. 前壁筋切片に扣ける acetylcholine の反応 (左). atropine 前投与後の acetylcholine の反応 (右). 反応は完全に抑制される．B．後壁筋切片に拈ける acetylcholine の反応(左). atropine 前投与後の acetylcholine の反応(右). tonic な収縮 反応は抑制されるが，スパイク状の収縮波は抑制されない。文：洗浄。

A.
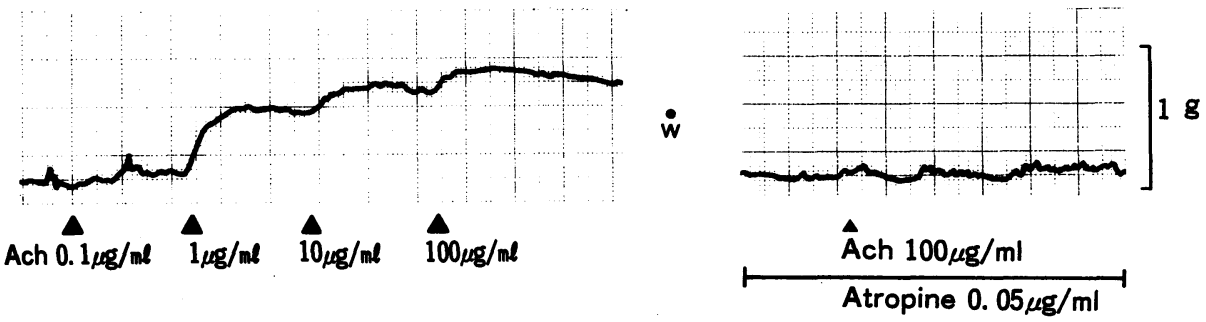

B.
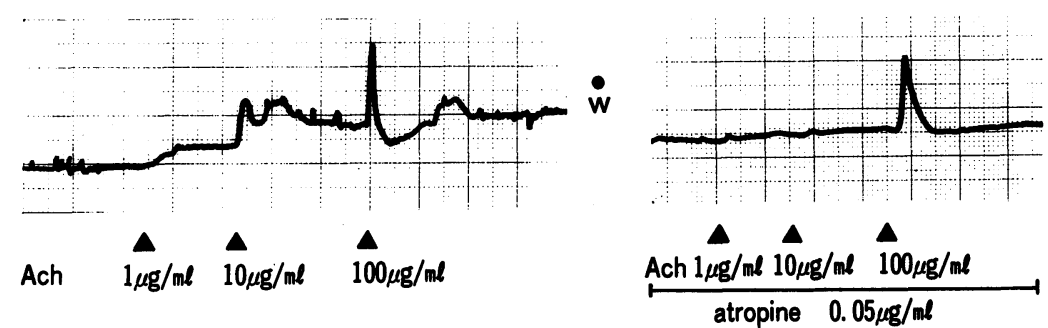

Ach $\quad \underset{1 \mu \mathrm{g} / \mathrm{ml}}{\Delta} \quad \overrightarrow{10}_{\mu \mathrm{g} / \mathrm{ml}} \quad \mathbf{1 0 0}_{\mu \mathrm{g} / \mathrm{ml}}$ 
らの反応は，排尿筇における Ach の効果を完全に抑制 すると考学られる atropine $0.05 \mu \mathrm{g} / \mathrm{ml}$ 前投与によっ ても注とんどで影響を受けなかった (Fig. 6)。なお， Ach $1 \mu \mathrm{g} / \mathrm{ml}$ および $10 \mu \mathrm{g} / \mathrm{ml}$ の低濃度では, ほとんど に反応がみられないか弱い収縮反応を示すのみであっ た。これらの反応の特徵については, 後に詳述する。

b) 軸方向筋切片

近位尿道の前壁と後壁から軸方向筋切片をそれぞれ 8 個採取し以下の検討を加えた。
前壁からの筋切片は, Ach $1 \mu \mathrm{g} / \mathrm{ml}$ から $100 \mu \mathrm{g} / \mathrm{ml}$ ま で投与すると濃度依存性の収縮反応を示し, atropine $0.05 \mu \mathrm{g} / \mathrm{ml}$ 前投与より完全に抑制された（Fig. 7 A). したがってこの反応も，排尿筋の場合と同様ムス カリン性受容体を介する反応であることが示された。

ところが，後壁から採取した軸方向筋切片に扣いて は，濃度依存性の收縮反応を示すが, Ach $10 \mu \mathrm{g} / \mathrm{ml}$ 投 与時より上昇した基線の上に不安定な収縮反応が加わ $\eta$, Ach $100 \mu \mathrm{g} / \mathrm{ml}$ 投与時にはスパイク状の収縮反応

Fig. 8 近位尿道周方向筋切片に抢ける交感神経作動薬の反応.

A. phenylephrine の反応. B. norepinephrine の反応 (上). prazosin 前投与後の norepinephrine の反応(下). 低濃度では弛緩反応を示すが, 高濃度では収縮反応を 示す. C. isoproterenol の反応.
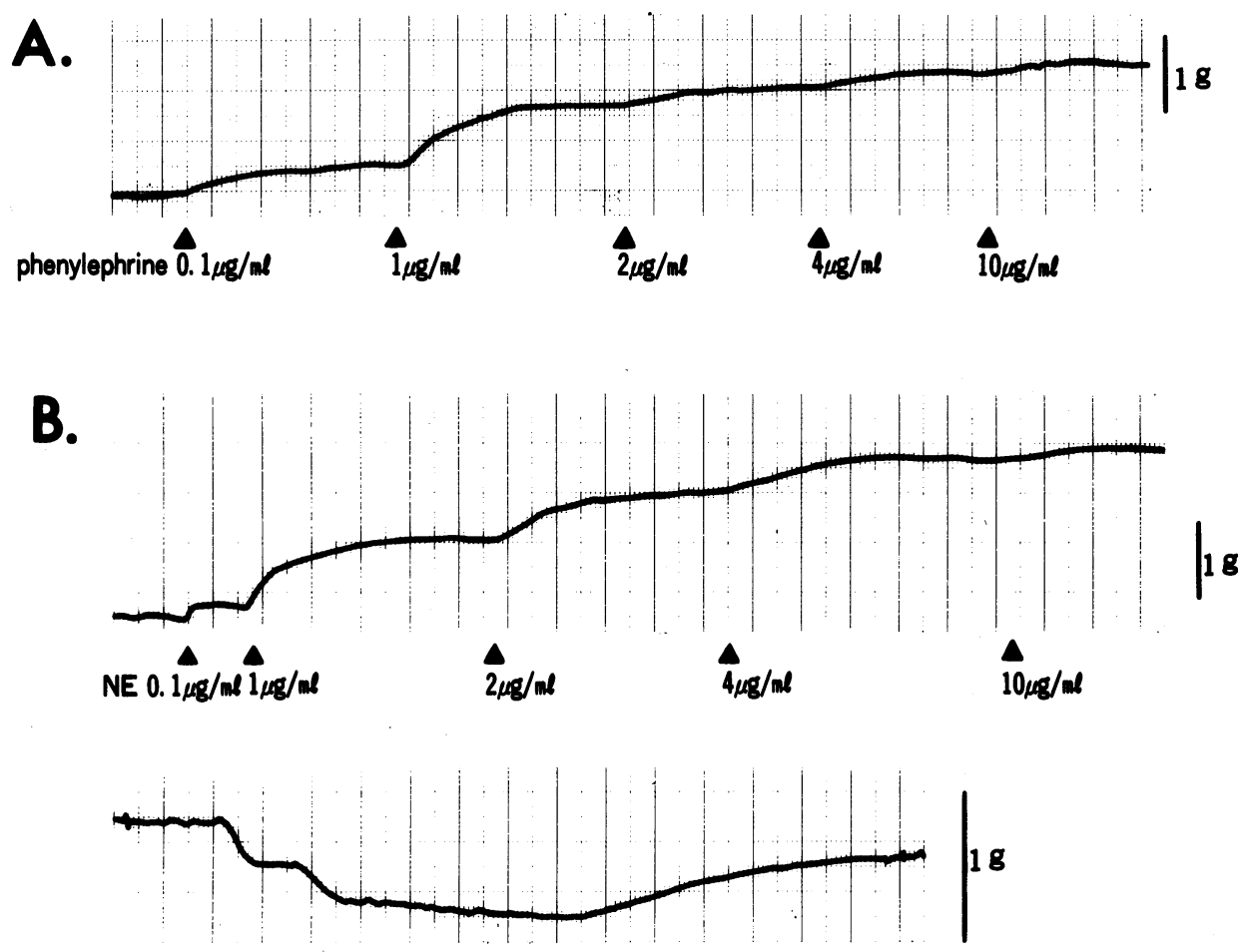

$\Delta \Delta$

$\frac{N E 0.1 \mu \mathrm{g} / \mathrm{ml} \quad 1 \mu \mathrm{g} / \mathrm{ml}}{\text { prazosin } 0.4 \mu \mathrm{g} / \mathrm{ml}}$
$10 \mu \mathrm{g} / \mathrm{ml}$

\section{$10 \mu \mathrm{cos}$}


に引き続く他緩反応が現われた。この切片を洗浄後, atropine $0.05 \mu \mathrm{g} / \mathrm{ml}$ をあらかじめ投与すると, tonic な収縮反応は抑制されたがスパイク状の収縮反応は依 然として抑制されず，それに続く他緩反応もわずかな がら記録された（Fig. 7B）。この反応についての解析 も後述する。

2. 交感神経作動薬に対する各部位での反応

a）周方向笳切片

膀胖䅡部から近位尿道までの区間で，各部位におい て10個の周方向筋切片を作製した，交感神経作動薬お よび拮抗薬に対してどの筋切片も同じ反応を示し, 周 方向筋切片の反応に関する限り部位による相違を認め なかった。すなおち, Fig. 8A に示すように phenylephrine $0.1 \mu \mathrm{g} / \mathrm{ml}$ より $10 \mu \mathrm{g} / \mathrm{ml}$ 投与により濃度依存 性の收縮反応を起こし, prazosin $0.4 \mu \mathrm{g} / \mathrm{ml}$ 投与によ り拮抗された. norepinephrine $(0.1 \mu \mathrm{g} / \mathrm{ml}$ から $10 \mu \mathrm{g} /$ $\mathrm{ml}$ ) も濃度依存性の収縮反応を引き起こした。しかし， prazosin $0.4 \mu \mathrm{g} / \mathrm{ml}$ を前投与して扣くと, norepinephrine $0.1 \mu \mathrm{g} / \mathrm{ml}$ 拈よび $1 \mu \mathrm{g} / \mathrm{ml}$ 投与時は弛緩反応を 示し, $10 \mu \mathrm{g} / \mathrm{ml}$ 投与時は再び収縮反応を認めた（Fig. $8 \mathrm{~B})$. isoproterenol $0.1 \mu \mathrm{g} / \mathrm{ml}$ より $10 \mu \mathrm{g} / \mathrm{ml}$ 投与では 濃度依存性の弛緩反応を示し（Fig. 8C), propranolol $10 \mu \mathrm{g} / \mathrm{ml}$ 投与により拮抗された。.以上より，近位尿道 の周方向筋切片には， $\alpha_{1}$ および $\beta$ 受容体が存在するこ とが明らかとなった。

b）近位尿道軸方向筋切片
近位尿道軸方向筋切片として前壁および後壁からそ れぞれ 5 切片を採取して検討を加えた。各切片とも phenylephrine $0.1 \mu \mathrm{g} / \mathrm{ml}$ から $10 \mu \mathrm{g} / \mathrm{ml}$ 投与, および norepinephrine $0.1 \mu \mathrm{g} / \mathrm{ml}$ から $10 \mu \mathrm{g} / \mathrm{ml}$ 投与により, 前壁扣よび後壁筇切片とも濃度依存性の収縮反応を示 した。また, isoproterenol $0.1 \mu \mathrm{g} / \mathrm{ml}$ から $10 \mu \mathrm{g} / \mathrm{ml}$ 投 与にて前壁扣よび後壁筋切片ともに弛緩反応が認めら れた (Fig. 9).

\section{Ach による反応の特異性に関する検討}

近位尿道の周方向筋切片括よび後壁からの軸方向切 片では, Ach 刺激に対して特徴的な反応を示し，これ はAchのムスカリン様作用ではなくニコチン様作用 であることが示唆されたのでこれを詳細に検討した。

\section{a）近位尿道周方向筋切片}

近位尿道周方向筋切片 120 個のらち 97 切片は Ach $100 \mu \mathrm{g} / \mathrm{ml}$ 投与時に，はじめに収縮し後に弛緩する 2 相性の反応を引き起こした(Fig. $5 \mathrm{~A})$. 前述した如く， この反応は排尿筋を完全に抑制した atropine 0.05 $\mu \mathrm{g} / \mathrm{ml}$ 投与にてもほとんど影響を受けなかった（Fig. $6)$.

次いで神経節刺激剤である DMPP $5 \mu \mathrm{g} / \mathrm{ml}$ を投与 すると，Ach 投与時と同じ 2 相性の反応を引き起こし た（Fig. 10A)。また神経節遮断剂である hexamethonium $50 \mu \mathrm{g} / \mathrm{ml}$ 前投与により収縮, 弛緩反応ともに消 失した。ささらに, tetrodotoxin $0.1 \mu \mathrm{g} / \mathrm{ml}$ 前投与によっ てもAch の反応は完全に抑制された(Fig. 10B). 以上

Fig. 9 近位尿道軸方向筋切片に打ける交感神経作動薬の反応.

A. norepinephrine の反応. B. isoproterenol の反応.
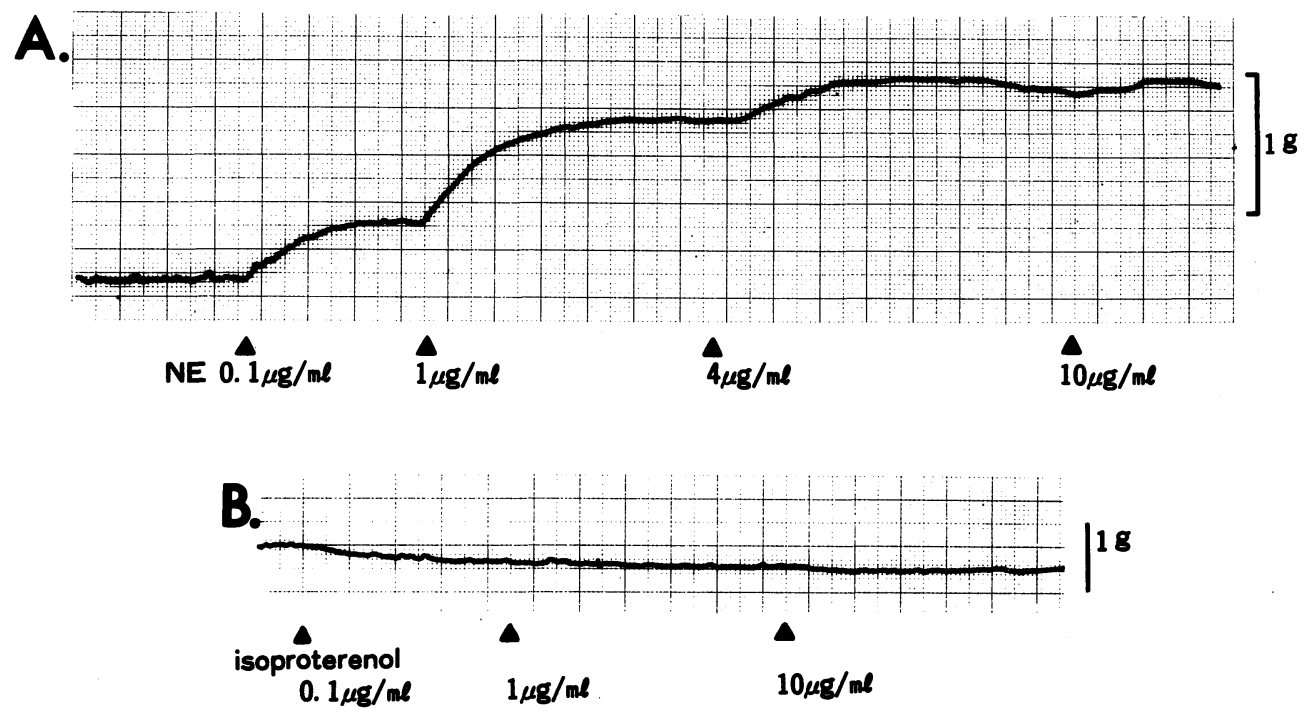
Fig. 10 近位尿道周方向筇切片における acetylcholine の反応に対する解析.

A. DMPPの反応(下). acetylcholine (上) と同じ反応が出現する. B. hexamethonium 前投与後の acetylcholine の反応 (上右). tetrodotoxin 前投与後の acetylcholine の反応 (下右)。いずれる反応は消失する．C. acetylcholine の反応（左） は, prazosin 前投与により収縮反応が消失し(中), propranolol 前投与で弛緩反応 が消失する (右). $\dot{\text { w }}$ : 洗浄.

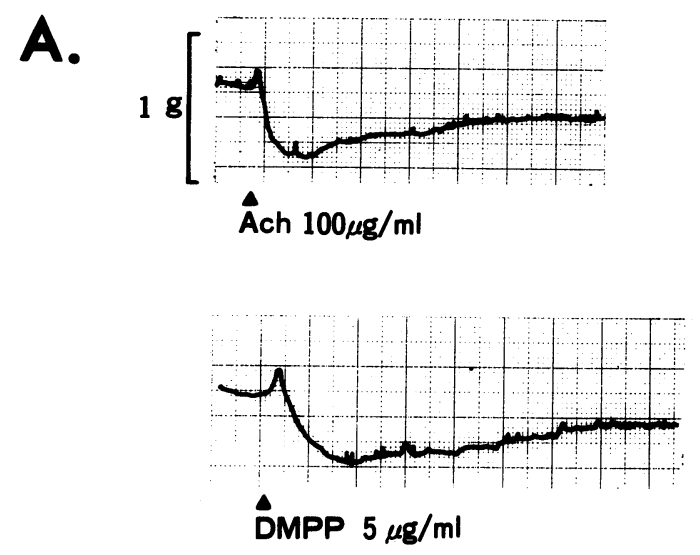

B.
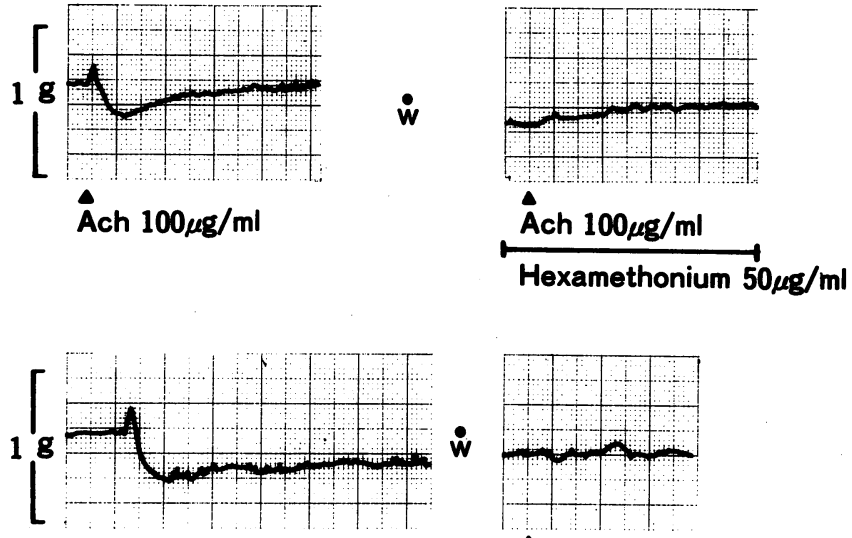

Âch $100 \mu \mathrm{g} / \mathrm{ml}$
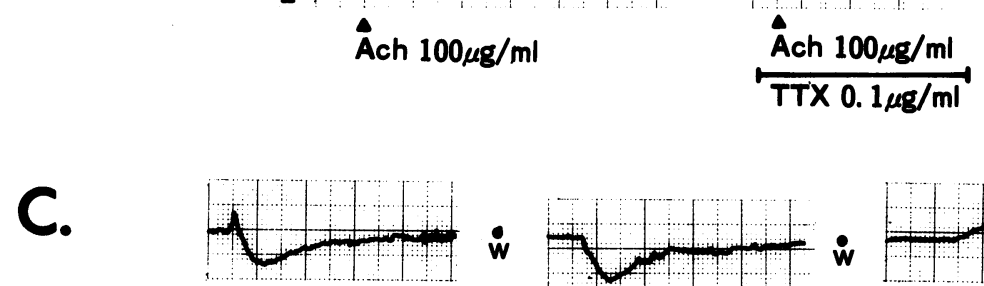

Ach $100 \mu \mathrm{g} / \mathrm{ml}$
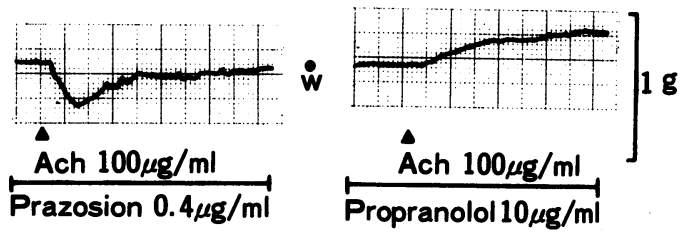

より, 近位尿道の示した 2 相性の反応は Ach のニコチ ン様作用によるものであることが明らかとなった。 次いで $\alpha_{1}$ 受容体遮断薬である prazosin $0.4 \mu \mathrm{g} / \mathrm{ml}$ を前投与すると，収縮反応だけが消失し弛緩反応の方
はむしろ増大した。さらに, $\beta$ 受容体遮断薬である propranolol $10 \mu \mathrm{g} / \mathrm{ml}$ 前投与により後の弛緩反応は完 全に消失した(Fig. 10C)。すなわち, 最初の収縮反応 は $\alpha_{1}$ 受容体を, 後の弛緩反応は $\beta$ 受容体を介する反応 
であることが示された。

一方，Ach $100 \mu \mathrm{g} / \mathrm{ml}$ 投与に対して収縮反応のみを 示した15筋切片について prazosin $0.4 \mu \mathrm{g} / \mathrm{ml}$ を前投

Fig. 11 近位尿道周方筋切片における acetylcholine の反応.

A. 収縮反応のみを示した筋切片は prazosin 前投 与により弛緩反応に逆転する。

B. 弛緩反応のみを示した筋切片は propranolol 前 投与により他緩反応が消失する. $\dot{\mathrm{w}}$ ：洗浄.

A

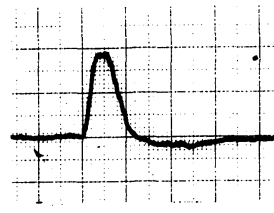
Ach $100 \mu \mathrm{g} / \mathrm{ml}$

B

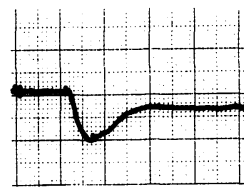

Ach $100 \mu \mathrm{g} / \mathrm{ml}$

\section{$\dot{w}$}

$\dot{w}$

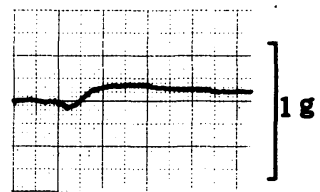

$\Delta$

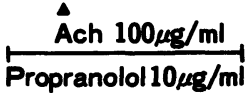

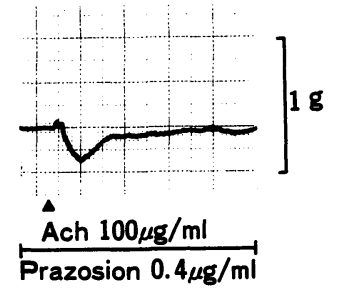

Fig. 13 近位尿道後壁筇切片に括ける acetylcholine の反応の解析. a） acetylcholine の反応. b) atropine 前投与後の acetylcholine の反応. スパイク 状の収縮波は抑制されない，c）prazosin 前投与後の acetylcholine の反応. 弛緩反 応が出現する.d） propranolol 前投与後の acetylcholine の反応. 他緩反応は消失す る. $\dot{\mathrm{w}}$ : 洗浄

a)

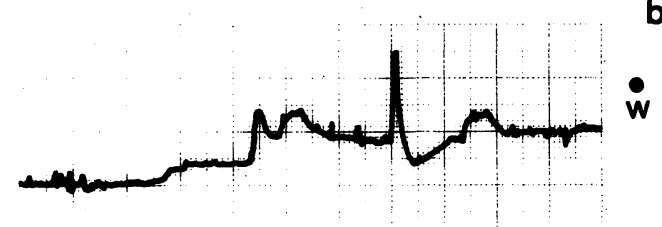

Ach
与すると，Ach による収縮反応は全例とも弛緩反応に 逆転した(Fig. 11A)。 また，弛緩反応のみを示した 8 筋切片に propranolol $10 \mu \mathrm{g} / \mathrm{ml}$ を前投与すると弛緩 反応は消失した (Fig. 11B). 以上より Ach 投与により 近位尿道周方向筇切片は 2 相性反応, 収縮反応, 弛緩 反応と異なった反応を示すが，これらの反応は本質的 にはAchのニュチン様作用によりアドレナリン受容 体を介して作用していることが明らかとなった。

さらに, norepinephrine 投与により収縮反応を引き 起こした筋切片に Ach $100 \mu \mathrm{g} / \mathrm{ml}$ を投与すると, 急速 な弛緩反応のみが引き起こされた（Fig. 12)。これは， norepinephrine 投与により $\alpha_{1}$ 受容体が刺激され筋の 緊張が高まった状態では, Ach の刺激は $\beta$ 受容体を介 する弛緩反応のみを起こすことを示している。

Fig. 12 近位尿道周方向筋切片に括ける norepinephrine 投与後の acetylcholine の反応. 急速な弛緩反応のみが出現する。

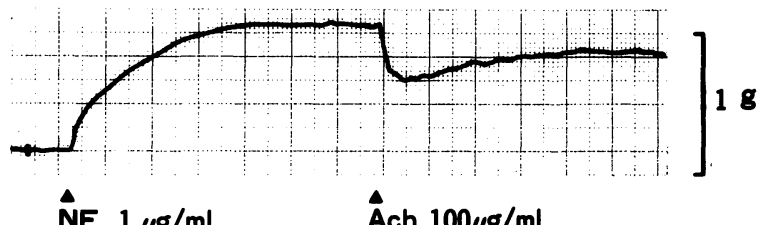

b)

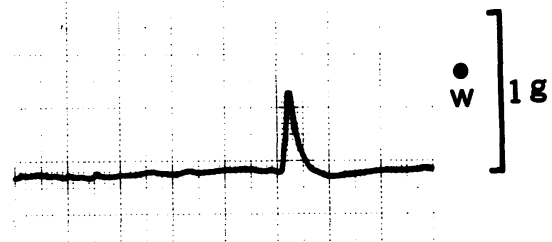

$\frac{\Delta_{\text {Ach } 1 \mu \mathrm{g} / \mathrm{ml} 10 \mu \mathrm{g} / \mathrm{ml}}^{\Delta} \dot{100 \mu \mathrm{g}} / \mathrm{ml}^{\Delta}}{\text { atropine } 0.05 \mu \mathrm{g} / \mathrm{ml}}$

d)

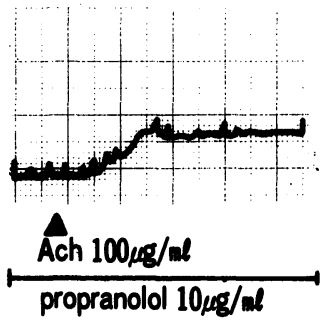


Table 1 detrusor : 排尿筋切片 circular : 近位尿道周方向筋切片 longitudinal :

近位尿道軸方向筋切片，Cは收縮反応， R は弛緩反応を示す。

1) Ach に対する各部位の反応

\begin{tabular}{l|c|c|c|c|c|c} 
& Ach & $\begin{array}{c}\text { atropine } \\
+ \\
\text { Ach }\end{array}$ & $\begin{array}{c}\text { prazosin } \\
+ \\
\text { Ach }\end{array}$ & $\begin{array}{c}\text { propranolol } \\
+ \\
\text { Ach }\end{array}$ & $\begin{array}{c}\text { hexamethonium } \\
+ \\
\text { Ach }\end{array}$ & $\begin{array}{c}\text { tetrodotoxin } \\
+ \\
\text { Ach }\end{array}$ \\
\hline detrusor & C & C は抑制 & & & & \\
\hline circular & C + R & 抑制されず & Cは抑制 & Rは抑制 & C.R とも抑制 & C.R とも抑制 \\
\hline longitudinal & C & C は抑制 & & & & \\
\hline
\end{tabular}

2）交感神経刺激剤に対する各部位の反応

\begin{tabular}{l|c|c|c|c|c}
\hline & phenylephrine & $\mathrm{NE}$ & $\begin{array}{c}\text { prazosin } \\
+ \\
\mathrm{NE}\end{array}$ & isoproterenol & $\begin{array}{c}\text { propranolol } \\
+ \\
\text { isoproterenol }\end{array}$ \\
\hline circular & $\mathrm{C}$ & $\mathrm{C}$ & $\mathrm{C}$ は抑制 & $\mathrm{R}$ & $\mathrm{R}$ は抑制 \\
\hline longitudinal & $\mathrm{C}$ & $\mathrm{C}$ & $\mathrm{C}$ は抑制 & $\mathrm{R}$ & $\mathrm{R}$ \&抑制 \\
\hline
\end{tabular}

b）近位尿道後壁軸方向筋切片

近位尿道後壁より採取した軸方向筋切片はAch 投 与により濃度依存性の収縮反応に加えて, スパイク状 の収縮波に引き続く驰緩反応が出現し, atropine 0.05 $\mu \mathrm{g} / \mathrm{ml}$ 前投与により tonic な収縮反応は抑制されスパ イク状の収縮波が出現することは前述した。このよう な反応が良好に記録された 5 切片を用いて以下同様の 検討を加えた。これらの切片を洗浄後 prazosin 0.4 $\mu \mathrm{g} / \mathrm{ml}$ を前投与すると, Ach 刺激により弛緩反応のみ が出現し, propranolol $10 \mu \mathrm{g} / \mathrm{ml}$ 前投与により弛緩反 応は消失した（Fig. 13）。したがって，近位尿道後壁の 軸方向筋切片においては，Ach 刺激によりムスカリン 性受容体を介する収縮反応が起こると同時に, ニコチ ン様作用により，アドレナリン受容体を介する特異的 な反応が出現することが明らかとなった。

最後にAch に対するこれらの反応が平滑筋による ものであることを確認するため, papaverinの効果を 検討した．近位尿道の周方向拈よび軸方向筋切片に打 いて, papaverin $10 \mu \mathrm{g} / \mathrm{ml}$ を前投与した後 Ach 100 $\mu \mathrm{g} / \mathrm{ml}$ を投与しても反応は全く出現しなかった。

尚, Table 1に, 自律神経刺激剤に対する近位尿道切 片の反応を示した。

一般に，蓄尿期（urine storage phase）には膀胱伸 展によって生ずる求心性インパルスが胸腰髄の交感神 経中枢を刺激し，交感神経の興奮が膀胼䅡部から近位 尿道を適度に収縮させると言われている ${ }^{12)}$ ，近位尿道 平滑筋の収縮がアドレナリンの受容体を介して起こる ことは，これまでin vitro studyやUPP (urethral pressure profile）を用いた尿道内圧測定法で報告され

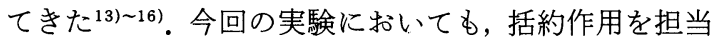
する周方向の筋切片では, phenylephrine や norepinephrine によって著明な収縮反応を示し prazosin で抑 制されることから, アドレナリン $\alpha_{1}$ 受容体が豊富に存 在し，ここが蓄尿期に拈ける括約機構 (continence mechanism) に重要な役割を果していると思われる。 なお， $\beta$ 受容体については，これが近位尿道輪状筋では 優位に存在するといら報告もあり ${ }^{17)}$, 今回の検討でも 周方向筋切片に $\beta$ 受容体の存在が示唆された. この役 割については後に詳しく考察する。

一方, 近位尿道の軸方向筋切片も, phenylephrine や norepinephrine や isoproterenol 投与に対して周方向 筋切片とほぼ同じ反応を示し，こちらにも $\alpha_{1}$ と $\beta$ 受容 体が存在することが明らかとなった。最近の Khanna $ら^{18)}$ や Hassouna $ら^{199}$ の実験でも本研究と同じ結果が 報告され，近位尿道では輪状括約筋と固有縦走筋の両 方がアドレナリン受容体を有すると解される。また， 蓄尿期に抢いて交感神経の興奮は輪状括約筋に対し $\alpha_{1}$ 受容体優位に作用しているものと考光られる。一 方, 軸方向筋切片に沶いても $\alpha_{1}$ 拈よび $\beta$ 受容体の存在 とその作用が明らかとなったが，これが continenceや 排尿時にどのような役割を果たしているのかは本研究 では結論を出すことはできなかった。今後更に近位尿 道の緥走筋と輪状筋の協調運動 (synergic interaction) ${ }^{191}$ に関する検討が必要であると思われる。

次に排尿期（voiding phase）に拈ける平滑筋性括約 筋 (smooth muscle sphincter) の弛緩機構を検討する が, 今回の実験で得られた Ach の特異な反応形式はこ 
の機構を考える上で興味深いものであった. Ach に対 する近位尿道筋切片（打もに周方向筋切片）の反応は, 排尿筋の場合と全く異なっていた。すなわち，Achに よって排尿笳はムスカリン性受容体を介する収縮反応 を示したが，近位尿道の周方向筋切片は初めに収縮し 後に弛緩する 2 相性の反応が大部分を占め, 残りはス パイク状の收縮反応驰緩反応がそれぞれ単独で出現し た。これらの反応はいずれも atropineにより影響され ないこと, DMPP 投与で同じ反応が起こすこと, hexamethonium または tetrodotoxin 投与により反応が 消失することょりニコチン様作用により作用している ことは明らかである。ささら， 2 相性の反応の場合， prazosin 前投与で最初の収縮が, propranolol 前投与 で後の弛緩反応がそれぞれ抑制されたこと，スパイク 状の収縮反応は prazosin 前投与により逆転すること， 弛緩反応が propranolol 前投与にて消失することなど から，Achはそのニコチン様作用で壁内神経節を刺激 した結果 norepinephrine が放出されアドレナリン受 容体を介して反応が引き起こされたものと考兄られ る. また, 反応形式は 2 相性, スパイク状の収縮反応, 弛緩反応と 3 種類の反応が認められたが，本質的には これらの反応は同じ機序で起こって招り，筋の緊張状 態により反応形式が異なって現われるにすぎないと考 えられる、すなわち, 筋の緊張が弱い状態では収縮反 応のみが出現し, 緊張が高まった状態では弛緩反応が 単独で現われ，その中間では 2 相性の反応が起こるも のと思われる。

一方, これまでの薬理学的研究をみると, Ach は近 位尿道に対してほとんど影響を及ぼさないか，ムスカ リン性受容体を介する反応のみであると報告してい

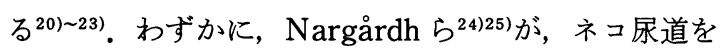
用いた in vitro studyによって著者と類似の結論を述 べているにすぎない，しかし，彼等の結果も尿道潅流 圧がAch 投与によってあるものは上昇し, あるものは 下降したりして一定でない。このような背景から今回 の実験をみると, Ach に対する特徵的反応は内尿道口 より約 $1 \mathrm{~cm}$ 遠位に招いて最も著明に現われ，ここょり 遠位や䅡部に近づくにつれ減弱する傾向にあった。特 に膀胱頝部では排尿筋成分によるムスカリン様反応の 上に尿道固有のニコチン様作用が混在しており, 部位 による反応上の相違が観察された。すなわち、これま での薬理学的検討は近位尿道の筋構築をあまり考慮せ ずに行なってきたため, 近位尿道の高さによって反応 が不安定になり混乱をまねいたものと思われる。
さて, 近位尿道の弛緩機構には, 最近の報告が示す ように神経による調節がかなり関与しているものと思 われる26) 28). 一般的には蓄尿反射によって六進してい た交感神経の活動が，排尿反射によって抑制され近位 尿道が弛緩すると考学られている。 しかしこの抑制が どのレベルで起こるのか, 現在も具体的なことは全く 不明である.1つの可能性として排尿時に pons の排 尿中枢から下降する反射性の運動ニューロンのインパ ルスが胸腰髄の交感神経中枢を抑制するといら考兄 方29) と，もら一つは末梢神経節レベルで抑制するとい ら考方方がある24)25(30)31).

近年の組織化学的研究によると, 骨盤神経や壁内神 経節に short adrenergic neuron が存在し, 近位尿道 に怙いても副交感神経と怙互いに連絡していることが

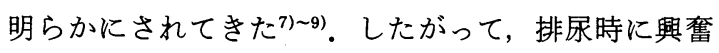
する副交感神経が節前性ニューロンでも節後性ニュー ロンでも近位尿道壁内神経節レベルでこの short adrenergic neuron と結合している可能性が十分考兄 られる。排尿直前までは先述したように交感神経の興 奮によって輪状筋の $\alpha_{1}$ 受容体が norepinephrine に よって占められ, 結果として尿道は収縮している。排 尿開始と同時に副交感神経が興奮し Ach が放出され ると, この short adrenergic neuron が興奮し, 今度 は $\beta$ 受容体の方に作用し輪状筋を弛緩させる。この機 序は, 本実験で norepinephrine で緊張を高められた輪 状方向筋切片が Ach 投与で弛緩反応のみを示す事実 によってもある程度肯定されると思われる。現実には 先述した瓷髄内レベルに拈ける交感神経中枢への抑制 が主な弛緩機構かもしれないが, 本研究で示された short adrenergic neuron の関与はその作用時間, 反応 の速さから見て近位尿道を排尿と同時にすばやく弛緩 させる補助促進的役割 (booster) が強いとも考兄られ る.いずれにせよ, 詳細については今後の研究が必要 である。

最後に近位尿道の機械的開口 (mechanical opening) 説と関連し, 軸方向筋切片との関連について述べる. 機械的開口説では排尿時に排尿筋の収縮により近位尿 道の縦走筋も収縮し, 尿道が短縮し膀脱䅡部が漏斗状 に開くといらものである(4) 6). 本実験において, 排尿筋 はAch 刺激に対して収縮反応を引き起こすが, 近位尿 道前壁の軸方向筋切片もAch に対して排尿筋と類似 した収縮反応を示し, atropineにより拮抗されること よりムスカリン性受容体を介する反応であることが明 らかとなった。 また近位尿道後壁の軸方向筋切片は 
Ach 刺激に対してこのようなムスカリン性受容体を 介寸る収縮反応に加兄てニコチン様作用による反応も 同時に起こっていることも示されたが，ニコチン様作 用の方はそれほど強いとは思われず，近位尿道は全体 として Ach 刺激に対して軸方向に収縮し，結果として は排尿時には短縮すると考光る方が妥当である．従っ て近位尿道には軸方向に排尿筋成分が入り込んでいる ことが推察された，以上より本実験に打いても，尿道 短縮による機械的開口の機構も一部は肯定されると考 えられ，今後更に筋構築を含めた近位尿道驰緩機構に ついての検討が必要と思われた。

\section{結 語}

雑種雌成犬を用い in vitro study にて近位尿道機能 を薬理学的に検討した。

1）近位尿道にはその構成筋組織の薬剤に対する反 応より $\alpha_{1}$ 抢よび $\beta$ 受容体の存在を強く示唆する結果 が得られた。

2）近位尿道軸方向筋切片は acetylcholine 投与に 対してムスカリン性受容体を介する収縮反応を示し た.

3）近位尿道周方向筋切片は acetylcholine 投与に 対してアドレナリン性受容体を介する初めに収縮し後 に弛緩する 2 相性の反応を示した。

4）近位尿道周方向筋切片に norepinephrine を投与 し収縮反応を起こした後, acetylcholineを投与すると $\beta$ 受容体を介する急速な驰緩反応のみが出現した.

5）3）4）の反応は acetylcholineのニコチン様作用 により short adrenergic neuronが刺激された結果引 き起こされたものと考えられた。

6）以上より, 排尿時に㧊ける近位尿道の弛緩機構 は，尿道の短縮による機械的開口と short adrenergic neuron の関与する弛緩反応の両者が関与しているも のと考觉られた。

稿を終えるに当り，御指導御校閲をいただいた恩師白岩 康夫教授に厚く感謝の意を表します。また，終始御指導御助 言をいただいた山口修講師に深く感謝いたします。なお，本 論文の要旨は第73回日本泌尿器科学会総会にて発表した。

\section{文献}

1) Gosling, J.A.: The anatomy of the bladder and urethra. In : Mundy, A.R., Stephenson, T.P., Wein, A.J. (eds) Urodynamics. principles, practice and application. Churchil Livingstone, 3-9, 1984.

2) Huisman, A.B.: Aspects on the anatomy of the female urethra with special relation to urinary continence. Contr. Gyenc. Obstet., 10, $1-31,1983$.

3) Tanagho, E.A., M. Ch. and Smith, D.R.: The anatomy and function of the bladder neck. Brit. J. Urol., 38, 54-71, 1966.

4) Lapides, J.: Structure and function of th internal vesical sphincter. J. Urol., 80, 341-353, 1958.

5) Woodburne, R.T.: Structure and function of the urinary bladder. J. Urol., 84, 79-85, 1960.

6) Hutch, J.A.: The internal urinary sphincter: A double-loop system. J. Urol., 105, 375-383, 1971.

7) Elbadawi, A. and Schenk, E.A.: A new theory of the innervation of bladder musculature. part 3. Postganglionic synapses in ureterovesicourethral autonomic pathways. J. Urol., 105, 372-374, 1971.

8) Schulman, C.C., Duarte-Esclante, O. and Boyasky, S. : The ureterovesical innervation. Brit. J. Urol., 44, 698-712, 1972.

9) Owman, Ch., Owman, T. and Sjöberg, N-O.: Short adrenergic neuron innervating the female urethra of the cat. Experimwntia, 27, 313-315, 1971.

10) McGuire, E., Wagner, F.M. and Weiss, R.M. : Treatment of autonomic dysreflexia with phenoxybenzamine. J. Urol., 115, 53-55, 1976.

11) Burnstock, G.: Past and current evdence for the purinergic nerve hypothesis. In : Baer, H.P. and Drummond, G.I. (eds), Phisiological and reguratory functions of adnosine and adenine nucleotides. Reven Press, New York, 3-32, 1979.

12) Mahony, D.T., Laferte, R.O. and Blais, D.J.: Integral storage and voiding reflexes. Urology, 9, 95-105, 1977.

13) Kleeman, F.J.: The physiology of the internal urinary sphincter. J. Urol., 104, 549-554, 1970.

14) Raz, S. and Caine, M.: Adrenergic receptors in the female canine urethra. Invest. Urol. 9, 319-323, 1972.

15) Awad, S.A. and Dowine, J.: The effect of adrenergic drugs and hypogastric nerve stimulation on the canine urethra: A radiologic and urethral pressure study. Invest. Urol., 13, 298-301, 1976.

16) Donker, P.J., Inanovici, F.I. and Noach, E.L.: Analyses of the urethral pressure profle by means of electromyography and the administration of drugs. Brit. J. Urol., 44, 180-193, 1972. 
17）香村衡一, 安田耕作, 中山朝行, 山域 豊, 浜 年 樹, 村山直人, 島崎 淳, 服部孝道: Continence Mechanism の研究. 第 2 報: 雑種雌成犬の尿道に 於ける alpha-receptor 及び betareceptor 所在に ついて. 日泌尿会誌，74，812-820, 1983.

18) Khanna, O.M.P., Barbieri, E.J., Altamura, M. and McMichael, R.: Vesicourethral smooth muscle: Function and relation tost ructure. Uroliogy, 18, 211-218, 1981.

19) Hassouna, M., Abdel-Hakim, A., Abdel-Rahman, M., Galeano, C. and Elihilali, M.M.: Response of the urethral smooth muscles to pharmacological agents. I. Cholinergic and adrenergic agonists and antagonists. J. Urol., 129, 1262-1264, 1983.

20) Persson, C.G.A. and Andersson, K.-E. : Adrenoceptor and cholincoeptor mediated effects in the isolated urethra of cat and guineapig. Clinic. Ex. Pharmacol. Physiol., 3, 415-426, 1976.

21) Ek, A., Alem, P., Andersson, K.-E. and Persson, C.G.A.: Adrenoceptor and cholinoceptor mediated responses of th isolated human urethra. Scand. J. Urol. Nephrol., 11, 97-102, 1977.

22）村山和夫：尿道の自律神経支配に関する薬理学的 研究. 日泌尿会誌, $71\lceil 33-49,1980$.

23）松尾重樹：犬近位尿道の自律神経支配に関する研 究一in vitro および in vivo 実験における薬理学 的比較検討一. 日泌尿会誌, 74, 1556-1574, 1983.

24) Nergårdh, A. and Boréus, O.: The functional role cholinergic receptors in the outlet region of the urinary bladdwr: An in vitro study in the cat. Acta Pharmacol. et Toxcol., 32, 467-480,
1973.

25) Nergårdh, A.: The interaction between cholinergic and adrenergic receptor funcctions in the outlet region of the urinary bladder. An in vitro study in the cat. Scand. J. Urol. Nephrol., 8, 108-113, 1974.

26) Jonas, U. and Tanagho, E.A.: Studies on vesicourethral reflexes. I. Urethral spincteric responses to detrusor stretch. Invest. Urol., 12, 357-373, 1975.

27) Ghoneim, M.A., Fretin, J.A., Gagnon, D.J. and Susset, J.G.: The influence of vesical distension on urethral resistance to flow: The explusion phase. Brit. J. Urol., 47, 663-670, 1975.

28) Kalaf, I.M., Topercer, A. and Elhilali, M.M.: Urethral pressure changes in reflex micturition. Invest. Urol., 17, 141-145, 1979.

29) Krane, R.J. and Siroky, M.B.: Classification on neuro-urologic disorders. In : Krane, R.J. and Siroky, M.B. (eds), Clinical Neuro-Urology, 1st. ed., p. 143-158, Little, Brown, co., Boston, 1979.

30) DeGroat, W.C. and Theobald, R.J.: Reflex activation of sympathetic pathways to vesical smooth muscle and parasympathetic ganglia by electrical stimulation of vesical afferents. J. Physiol., 259, 223-237, 1976.

31) Matiasson, A., Andersson, K.-E. and Sjögren, C.: Adrenoceptor and cholinoceptors controlling noradrenaline release from adrenergic nerves in the urethra of rabbit and man. J. Urol., 131, 1190-1195, 1984.

（1986年 2 月 28 日受付，特別揭載） 